\title{
Obstetric Outcome of Pregnancies Complicated by Domestic Violence
}

\author{
Mathias Ankama1, Adekunle 0. Oguntayo ${ }^{1 *}$, Jefry T. Akuse ${ }^{2}$ \\ ${ }^{1}$ Department of O \& G, ABU Teaching Hospital Shika, Zaria, Nigeria \\ ${ }^{2}$ Sefa Specialist Hospital, Kaduna, Nigeria \\ Email: fayokunmi@yahoo.co.uk
}

Received 27 June 2014; revised 20 July 2014; accepted 15 August 2014

Copyright (C) 2014 by authors and Scientific Research Publishing Inc.

This work is licensed under the Creative Commons Attribution International License (CC BY).

http://creativecommons.org/licenses/by/4.0/

(c) (i) Open Access

\begin{abstract}
Background: Domestic violence is a pattern of assault and behavior perpetrated by one partner against the other. Historically most of those oppressed by domestic violence have been women. The lifetime prevalence of domestic violence against women is $10 \%-69 \%$. Though this violence might have started or escalated during pregnancy, pregnancy specific prevalence is between $1 \%$ $20 \%$. The objective was to determine the prevalence and obstetric complications. Domestic violence is against pregnant women in tertiary clinic of a developing nation. Methodology: It was a hospital based cross-sectional case control study conducted within the period of one year. Close ended questionnaires were administered. Result: Two hundred and seventy patients were recruited. The lifetime prevalence of physical violence against women was $28.5 \% .12 .5 \%(5 / 40)$ of victims smoke cigarettes; the prevalence of alcohol intake by the victims was $45 \% .72 .5 \%$ of partners of victims smoke as compared to $25.5 \%$ of partners of non victims. Unemployed women were victims of domestic violence far more than the employed women. Pregnant women who are victims of physical violence are more likely to suffer adverse pregnancy outcome. Violence in pregnancy is quite commoner than most of the conditions routinely screened for during antenatal care. The association of such violence with significant maternal and fetal/neonatal morbidity and mortality emphasizes the fact that domestic violence is not just a social problem but a feto-maternal health hazard that requires the input of every stakeholder to address.
\end{abstract}

\section{Keywords}

Obstetric, Violence, Pregnant, Domestic

\section{Introduction}

Domestic violence is a pattern of assault and behavior perpetrated by one partner against the other. It can include "Corresponding author. 
physical, sexual, and psychological attacks as well as emotional intimidation, verbal abuse, destruction of pets and property, marital rape, and social isolation [1]-[6].

Domestic violence can be found in all age groups and socioeconomic strata and occurs in homosexual as well as heterosexual relationships [1] [7].

Historically most of those oppressed by domestic violence are women [1] [3] [7] [8].

The incidence of physical violence and sexual abuse against women has been on the increase [3] [8]. This increased incidence is particularly higher during pregnancy and the post partum period [8]-[11].

Domestic violence against women is perhaps the most pervasive yet the least recognized human right abuse in the world.

The lifetime prevalence of domestic violence against women is significantly high (10\% - 69\%) [12]. Though this violence might have started or escalate during pregnancy. Pregnancy specific prevalence of domestic violence varies between 1\% - 20\% [3] [5] [6] [13]-[16]. According to a study done in Ghana, Kwawukume and Kwawukume, found that $54 \%$ of pregnant women studied had suffered violence in the form of physical assault and $44 \%$ were forced to have sex when they did not want to. Odujinrin reported an incidence of $30 \%$. Ezegwui et al. [17] found a prevalence of 37.2\% among antenatal clinic patients of Federal Medical Centre Abakaliki. In ABU Teaching Hospital Zaria, Ameh and Abdul [18] found a prevalence of 28\% among antenatal clinic attendees. Twenty-two percent of the patients were forced to have sex while the rest were physically assaulted. The culprits were the spouses in $34 \%$, in-laws in $26 \%$ and boyfriends in $22 \%$.

The combination of violence and poverty forces many women to remain in violent and dangerous relationships where they are often subjected to rape and HIV infection by their HIV positive partners [19]-[21]. In fact, recent research in Uganda showed that abusive men often intentionally infected their partners with HIV [21].

Different people attribute different reasons to the cause of domestic violence. Worldwide, studies identify a list of events that are said to provoke or spur violence. This includes disobedience to husband, the lack of submission, and expressing suspicion of infidelity to mention a few.

Cheryl Bernard [22], director Austria’s Ludwig Bolzmann Institute noted that:

"Violence against women in the family takes place because the perpetrator and their environment encourage them to feel that this is an acceptable exercise of male prerogative, a legitimate and appropriate way to relieve their own tension in condition of stress, or just to enjoy the feeling of supremacy”.

Domestic violence during pregnancy has been associated with serious consequences for women and their children. Pregnant women who experience violence are more likely to delay seeking antenatal care because of deprivation or restriction, unable to gain weight appropriately, and come down with sexually transmitted disease. Persily and Abdulla [23] found a significant relationship between sexually transmitted disease tobacco use and marital status and domestic violence. The prevalence of unwanted or mistimed pregnancy is also higher because of sexual abuse or denial to use contraception. Abortions, antepartum haemorrhage, preterm labour, fetal distress and perinatal mortality rate are also higher among abused women.

In a recent survey of two hospitals in Vancourver, British Columbia Janssen et al. [24] found 33\% of women who were exposed to violence to have had at least one previous abortion as compared to $21 \%$ of other women. Other findings include significantly high odds ratios for antepartum haemorrhage (3.8), intra uterine growth restriction (3.1) and prenatal death (8.1). In the analysis adjusted for use of alcohol, illicit drugs and tobacco, women who were physically abused continued to have an elevated risk of antipartum haemorrhage (odds ratio 3.5) and prenatal death (7.3); the odds ratio for intrauterine growth restriction was elevated (2.8), although it was only marginally significant. Further stratified analysis to examine the association between substance abuse, physical abuse and adverse pregnancy outcome revealed a significant association of physical violence with an increased rate of antepartum haemorrhage among known users of alcohol, illicit drugs or tobacco (relative risk 3.5 - 3.8) and of intrauterine growth restriction among users of those substances (5.3 - 7.1). Perinatal death was positively associated with physical abuse among known users of alcohol (10.1) and among users of illicit drugs. Fernandez and Krueger [25] found the prevalence of preterm delivery to be $22 \%$ among victims as compared to $9 \%$ among those that did not suffer. $16 \%$ had low weight babies as compared with $6 \%$ in controlled group.

Domestic violence can also lead to maternal death. Ganatra, Coyaji and Rao [29] found domestic violence responsible for $16 \%$ of all maternal death in a study of 400 villages and 7 hospitals in the district of Maharasta India. Domesti violence in pregnancy is therefore a focus attack that puts not just one life but two at risk. It also differs from other forms of violence where the head is usually attacked; battering of pregnancy women tends to be directed at the breast, abdomen or the genitals [25]-[29]. 
For domestic violence and the law, it is encouraging to note that most constitutions of civilized nations in the world provide for basic right of individuals known as fundamental human rights. It is most disheartening to acknowledge the fact that, most traditional norms and cultures do not provide sources of redress for victims of abuse, and most countries don't have specific laws against domestic violence. In the whole African continent, it is only South Africa that has enacted legislation outlawing domestic violence [30]-[32].

The victims of domestic violence in pregnancy, present with features of increased physical and psychological stress, inadequate prenatal care utilization, poor nutrition and weight gain, and increased maternal behavioral risks (cigarette, alcohol and substance abuse). Physical trauma can cause abruption placenta, preterm labour, and preterm premature rupture of membranes, maternal and fetal injuries and demise [28] [33].

Although abused women seek medical care frequently, as few as $5 \%$ are correctly identified by the practitioner to whom they turn for help [14]. Barriers to diagnosis include practitioner's lack of knowledge or training, the lack of recognition of the widespread prevalence of the problem, time constraints, fear of offending the patient, and a feeling of powerlessness in the area of treatment [14] [21] [34]-[36].

A high index of suspicion and thorough understanding of the multiple adverse health effects and high rate of physical and psychological morbidity associated with domestic violence must be acquired by all health care professionals. This will ensure early detection and appropriate treatment and therefore reduces the drain on health care resources. The obstetrician and gynecologist certainly have a medical and ethical obligation to intervene on behalf of the pregnant patient [37].

To this end we decide to determine the prevalence and obstetric complications of domestic violence against pregnant women attending tertiary health facility in a developing nation.

\section{Study Design}

The study was a hospital based cross-sectional case control study conducted within the period 1st July to 30th November 2006. Close ended questionnaires was designed and were administered.

The study population was made up of women attending booking clinic, antenatal clinic, women who came to deliver and those attending post-natal clinic.

The sampling method was a convenient sampling; every other patient who consents to partake in the study was included. The controls in this study were the women that were not exposed to violence in the study.

The sample size was calculated based on the estimated pregnancy specific prevalence of domestic violence of $20 \%$ (0.2) [5] [6] using the formula by D.W. Taylor and got 270 including $10 \%$ attrition.

The study was incorporated into the regular booking antenatal, postnatal clinics and daily wards activities. Two hundred and seventy patients were recruited for the study; two hundred and fifty two results were analyzed.

Data collected from both the administration of Questionnaire and the follow up of patient case notes and delivery suite records are presented below. The data were analyzed using the Epi-info statistical package.

The outcomes of pregnancies complicated by domestic violence are compared to those of pregnancies not complicated by domestic violence using ratios and proportions. Statistical significance value was set at P-value $<0.05$.

\section{Ethical Consideration}

Consent to carry out the research was obtained from ethical and scientific committee of the Hospital. Informed consent was obtained from the patients. The right of patient to participate or not was respected.

The results obtained are presented in simple frequency distribution and proportions. Data management and statistical analysis was employed to determine the effect, if any, of physical violence on maternal, social habits, obstetric outcome, and neonatal outcome and to relate maternal demographic factors to the prevalence of domestic violence. EPI info 6 statistical package were used to analyze the data.

\section{Discussion}

The prevalence of domestic violence in pregnancy is unacceptably high. The lifetime prevalence of physical violence against women was found to be $28.5 \%$ from this study. This value is within the range of those found by other researchers' i.e. Odunjirin [16] (30\%), Ameh and Abdul [18] (28\%). The pregnancy specific prevalence of physical violence $(15.9 \%)$ and sexual violence $(15.1)$ in this study are all within the limits quoted by most lite- 
ratures. McFarlane, Parker and Soekan reported a prevalence of one in six (16.6\%). Violence can occur anytime in pregnancy with the husband and boyfriends as the main assailants (Table 1 and Table 2).

Social factors associated with high prevalence of domestic violence include both assailant and victim's imbibing the use of alcohol and smoking. Table 2 shows that 12.5\% (5/40) of victims smokes cigarette as compared to $9.4 \%$ of none victims, the prevalence of alcohol intake by victims was $(18 / 40=45 \%)$ as compared to $12 / 192=6.3 \%$ by non victims $72.5 \%$ (29/40) of partners of victims smokes as compared to $25.5 \%$ (49/192) of partners of non victims. Similar findings have been reported by other researchers [2] (Tables 3-5). The incidence of domestic violence is significantly higher in women that are not employed when compared to women that are employed (Table 6). Educational attainment of both victim and assailant does not seem to protect against domestic violence. Married women are more likely to be predisposed to physical and sexual violence than single, separated or divorced women. Pregnant women who are victims of one form of domestic violence are more predisposed to the others (Table 7).

Table 1. Frequency distribution of forced sexual intercourse and physical violence (ever).

\begin{tabular}{|c|c|c|c|c|}
\hline \multirow{2}{*}{$\begin{array}{l}\text { Force sexual intercourse \& physical violence } \\
\text { Have you ever been forced to have sexual intercou } \\
\text { against your will? }\end{array}$} & \multicolumn{2}{|c|}{ Force sexual intercourse number \% } & \multicolumn{2}{|c|}{ Physical violence number \% } \\
\hline & & & & \\
\hline Yes & 49 & 19.5 & 65 & 25.8 \\
\hline No & 196 & 78.1 & 187 & 74.2 \\
\hline No response & 6 & 2.4 & & \\
\hline \multicolumn{5}{|l|}{$\begin{array}{l}\text { If forced, age at the first being forced to have } \\
\text { sexual intercourse: }\end{array}$} \\
\hline Less than 12 years & 6 & 2.4 & 32 & 12.7 \\
\hline 12 - 18 years & 10 & 4.0 & & \\
\hline More than 18 years & 28 & 11.1 & 188 & 74.6 \\
\hline Can't remember & 5 & 2.0 & & \\
\hline No response & 202 & 80.5 & & \\
\hline \multicolumn{5}{|l|}{ If forced who forced sexual intercourse? } \\
\hline Boyfriend & 132 & 52.4 & & \\
\hline Husband & 62 & 24.6 & & \\
\hline \multicolumn{5}{|l|}{ Acquaintance } \\
\hline Stranger & 52 & 20.6 & & \\
\hline In-law & 138 & 54.8 & & \\
\hline Relations & 62 & 24.6 & & \\
\hline \multicolumn{5}{|l|}{ No response } \\
\hline Father & 17 & 6.7 & & \\
\hline Mother & 22 & 8.7 & & \\
\hline Brother/sister & 8 & 3.2 & & \\
\hline Aunt/uncle & 1 & 0.4 & & \\
\hline In-laws & 1 & 0.4 & & \\
\hline More than one relation & 3 & 1.2 & & \\
\hline
\end{tabular}

Sexual violence was essentially carried out by relations and friends and the minus were not left out of these violence. 
Table 2. Frequency distribution of forced sexual intercourse \& physical violence in current pregnancy.

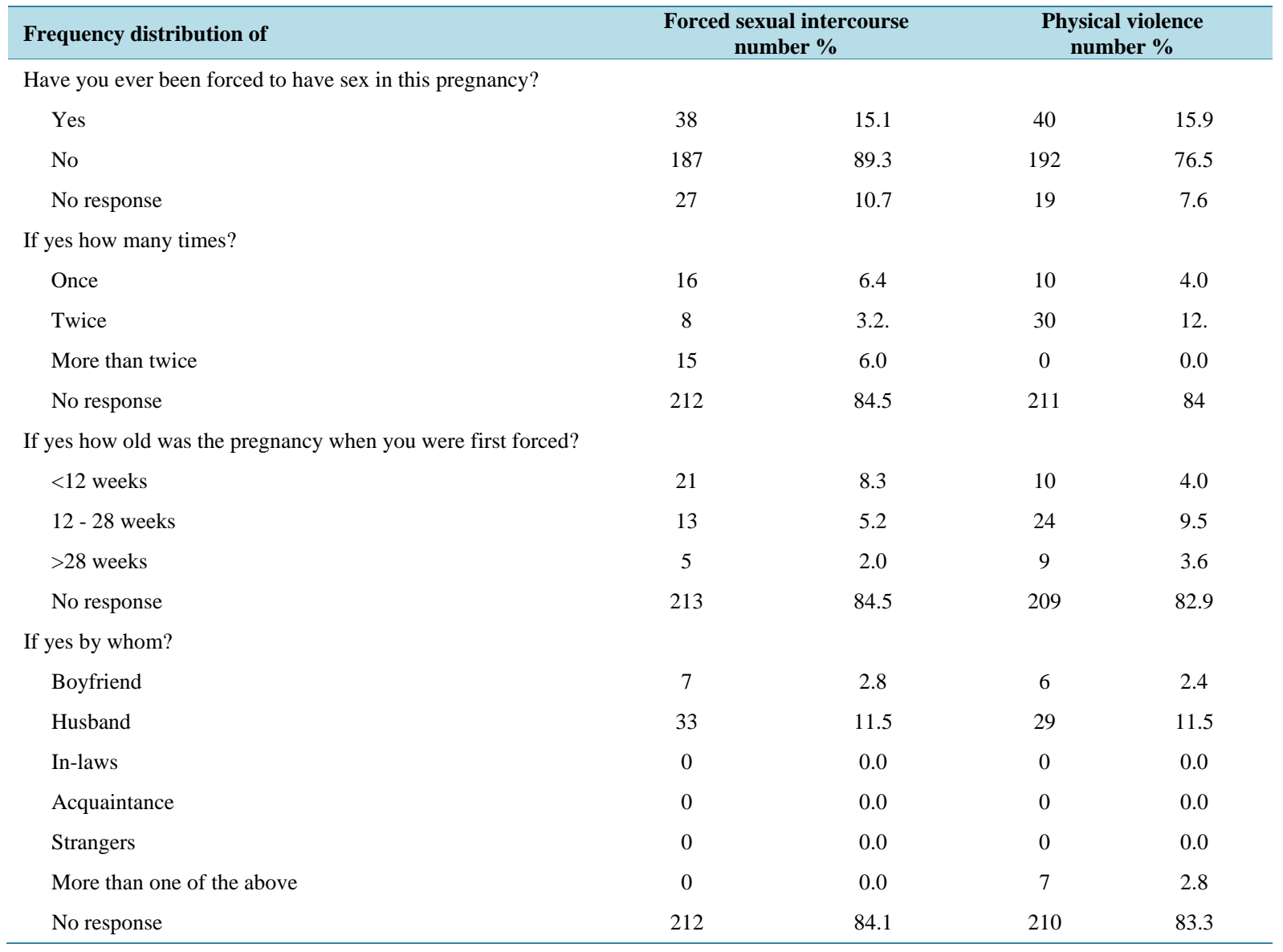

Domestic violence cuts across all gestational age in pregnancy, but commoner in the 1st trimester major colprits were the husbands.

Table 3. Prevalence of physical violence amongst pregnant women by correlate (social factors).

\begin{tabular}{|c|c|c|c|c|c|}
\hline \multirow{2}{*}{ Attribute } & \multicolumn{4}{|c|}{ Physical violence } & \multirow[t]{2}{*}{ Odd ratio } \\
\hline & Yes & $\%$ & No & $\%$ & \\
\hline \multicolumn{6}{|c|}{ Do you smoke? } \\
\hline Yes & 5 & 20.8 & 18 & 75 & $2.7(2.33-5.48)$ \\
\hline No & 28 & 13.7 & 164 & 80 & $\mathrm{P}<0.05$ \\
\hline No resp. & 7 & 31.8 & 10 & 45.5 & Significant \\
\hline \multicolumn{6}{|c|}{ Do you drink alcohol? } \\
\hline Yes & 18 & 58.1 & 12 & 38.7 & $21.92(8.17$ - 60.69) \\
\hline No & 15 & 7.1 & 179 & 84.8 & $\mathrm{P}<0.05$ \\
\hline No resp. & 7 & 77.8 & 1 & 11.1 & Significant \\
\hline \multicolumn{6}{|c|}{ Does your partner drink alcohol? } \\
\hline Yes & 19 & 17.9 & 83 & 78.3 & $1.8(0.56-2.46)$ \\
\hline No & 21 & 14.2 & 108 & 75.0 & $\mathrm{P}>0.05$ \\
\hline No resp. & 0 & 0.0 & 1 & 0.5 & Not significant \\
\hline \multicolumn{6}{|c|}{ Does he smoke? } \\
\hline Yes & & & & & $7.64(3.35$ - 17.17) \\
\hline No & 29 & 35.4 & 49 & 59.8 & $\mathrm{P}<0.05$ \\
\hline No resp. & 11 & 6.5 & 142 & 84.5 & Significant \\
\hline
\end{tabular}

Alcohol and cigarette smoking by both all have impact on domestic violence. 
Table 4. Prevalence of violence amongst ANC women by correlate (obstetric factors).

\begin{tabular}{|c|c|c|c|c|c|}
\hline \multirow{2}{*}{ Attribute } & \multicolumn{4}{|c|}{ Physical violence } & \multirow[t]{2}{*}{ Odd ratio } \\
\hline & Yes & $\%$ & No & $\%$ & \\
\hline \multicolumn{6}{|c|}{ Gestational age at booking } \\
\hline$<28$ wks & 7 & 13.5 & 42 & 80.8 & 1.825 .48 \\
\hline$>28$ wks & 12 & 7.7 & 131 & 84.0 & $(0.6-5.39)$ \\
\hline Un-booked & 20 & 47.6 & 19 & 45.2 & $\mathrm{P}<0.05$ \\
\hline No record & 1 & 2.5 & 0 & 0.0 & Insignificant \\
\hline \multicolumn{6}{|c|}{ Number of ANC attendance } \\
\hline$<6$ & 18 & 22.0 & 53 & 64.4 & $13.70(3.59$ - 61.27) \\
\hline$>6$ & 3 & 2.36 & 121 & 95.3 & $\mathrm{P}<0.05$ \\
\hline No attendance & 19 & 42.2 & 21 & 50.0 & Significant \\
\hline \multicolumn{6}{|c|}{ Haemoglobin concentration at first presentation. } \\
\hline$<10 \mathrm{gms} / \mathrm{dl}$ & 5 & 17.2 & 20 & 69.0 & $1.52(0.46-4.78)$ \\
\hline$>10 \mathrm{gms} / \mathrm{dl}$ & 27 & 13.1 & 164 & 79.6 & $\mathrm{P}>0.05$ \\
\hline No record & 8 & 50 & 8 & 50 & Insignificant \\
\hline \multicolumn{6}{|c|}{ Abnormal vaginal discharge } \\
\hline Present & 22 & 43.1 & 29 & 54.9 & $2.76(1.26-2.18)$ \\
\hline Absent & 17 & 8.8 & 162 & 83.5 & $\mathrm{P}<0.05$ \\
\hline No response & 1 & 16.7 & 1 & 16.7 & Significant \\
\hline \multicolumn{6}{|c|}{ Urinary tract infection } \\
\hline Present & 1 & 3.7 & 17 & 63.0 & $2.22(0.41-3.47)$ \\
\hline Absent & 34 & 15.5 & 175 & 79.9 & $\mathrm{P}>0.05$ \\
\hline No response & 5 & 12.5 & 0 & 0.0 & Insignificant \\
\hline \multicolumn{6}{|l|}{ Bleeding PV } \\
\hline Present & 11 & 84.6 & 21 & 7.7 & 72.45 (9.07 - 15.57) \\
\hline Absent & 129 & 12.2 & 191 & 80.3 & $\mathrm{P}<0.05$ \\
\hline No response & 0 & 0.0 & 0 & 0.0 & Significant \\
\hline Abortion & & & & & $1.6(1.34-8.80)$ \\
\hline Present & 1 & 25 & 3 & 75 & $\mathrm{P}<0.05$ \\
\hline Absent & 39 & 15.8 & 189 & 76.5 & Significant \\
\hline PROM & & & & & $5.87(2.24-15.45)$ \\
\hline Present & 12 & 48.0 & 13 & 52.0 & $\mathrm{P}<0.05$ \\
\hline Absent & 28 & 12.4 & 178 & 79.1 & Significant \\
\hline \multicolumn{6}{|l|}{ Preterm labour } \\
\hline Present & 12 & 34.3 & 23 & 65.7 & $4.08(1.62$ - 9.89) \\
\hline Absent & 22 & 10.5 & 169 & 80.5 & $\mathrm{P}<0.05$ \\
\hline No response & 6 & 100 & 0 & 0.0 & Significant \\
\hline Prolong labour & & & & & $36.03(6.98-249.06)$ \\
\hline Present & 11 & 84.6 & 2 & 15.4 & $\mathrm{P}<0.05$ \\
\hline Absent & 29 & 12.2 & 190 & 79.8 & Significant \\
\hline \multicolumn{6}{|l|}{ Mode of delivery } \\
\hline SVD & 27 & 17.4 & 134 & 77.0 & $2.37(1.5-3.5)$ \\
\hline OVD & 2 & 5.1 & 32 & 82.1 & $\mathrm{P}<0.05$ \\
\hline CS & 11 & 31.4 & 23 & 65,7 & Significant \\
\hline
\end{tabular}

OVD: operative vaginal delivery. The violent groups booked late, attends antenedtal clinic less frequently and about $40 \%$ of them have had an episode of bleeding in pregnancy suggesting threatened abortion. During the study period, there were three maternal death in the department, one of the patients died of severe antepartum haemorrhage preceded by domestic violence. 
Table 5. Prevalent of domestic violence amongst pregnant women by correlate (neonatal factor).

\begin{tabular}{|c|c|c|c|c|c|}
\hline \multirow{2}{*}{ Attribute } & \multicolumn{4}{|c|}{ Physical violence } & \multirow[t]{2}{*}{ Odd ratio } \\
\hline & Yes & $\%$ & No & $\%$ & \\
\hline \multicolumn{6}{|l|}{ Apgar score at } \\
\hline $5 \mathrm{~min}$. & & & & & 9.67 \\
\hline$<6$ & 23 & 42.6 & 28 & 51.9 & $(4.11-23.07)$ \\
\hline$>6$ & 13 & 7.2 & 153 & 84.5 & $\mathrm{P}<0.05$ \\
\hline No response & 4 & 25.0 & 11 & 68.8 & Significant \\
\hline \multicolumn{6}{|l|}{ Birth weight } \\
\hline$<1.5 \mathrm{~kg}$ & 1 & 11.1 & 8 & 88.9 & 6.0 \\
\hline $1.5-2.49 \mathrm{~kg}$ & 21 & 52.5 & 28 & 14.6 & $(0.93-2.58)$ \\
\hline$>2.5 \mathrm{~kg}$ & 18 & 9.4 & 155 & 81.2 & $\mathrm{P}<0.05$ \\
\hline No response & 0 & 0.0 & 1 & 0.5 & Significant \\
\hline \multicolumn{6}{|l|}{ Neonatal } \\
\hline Sepsis & & & & & 1.21 \\
\hline Present & 4 & 23.8 & 16 & 76.2 & $(0.32-4.20)$ \\
\hline \multirow[t]{2}{*}{ Absent } & 35 & 15.2 & 180 & 78.3 & $\mathrm{P}>0.05$ \\
\hline & & & & & Insignificant \\
\hline \multicolumn{6}{|l|}{ Perinatal } \\
\hline \multicolumn{6}{|l|}{ Mortality } \\
\hline Present & 6 & 28.6 & 12 & 57.1 & 2.62 \\
\hline \multirow[t]{3}{*}{ Absent } & 34 & 14.8 & 178 & 77.4 & $(0.81-8.21)$ \\
\hline & & & & & $\mathrm{P}>0.05$ \\
\hline & & & & & Insignificant \\
\hline
\end{tabular}

Domestic violence was only evident in weight of these neonates at birth.

Pregnant women who are victims of physical violence are more likely to suffer adverse pregnancy outcome. The odd ratios are significantly elevated for number of times patient attended antenatal clinic (odd ratio 13.7), abnormal virginal discharge (odd ratio 2.6) bleeding in pregnancy (odd ratio 72.45), abortion (1.6), premature rupture of fetal membranes (5.87) preterm labour (4.08) as well as high rate of operative deliveries among victims (odd ratio 2.37) (Table 3). These findings are consistent with findings of other researchers. The odd ratios are however not elevated for gestational age at booking, haemoglobin concentration at booking, and the prevalence of urinary tract infection. There is a significant relationship between physical violence and neonatal outcome. The elevated odd ratio for apgar score $<6$ at 5 min (odd ratio 9.67), low birth weight (odd ratio 6) signifies bad neonatal outcome.

During the study period there were three maternal deaths in the department, two of the women died of obstetric factors, one died of severe antepartum haemorrhage precipitated by physical assault by her husband. This denotes physical violence as a cause of 33\% of maternal mortality within the period of this study. Though this figure is much higher than that found by Ganatra et al., domestic violence is a major cause of maternal mortality.

\section{Conclusion}

Violence against pregnant women is a common practice that has remained for generations despite civilization. 
Table 6. Prevalence of domestic violence amongst pregnant women by demographic factors.

\begin{tabular}{|c|c|c|c|c|c|}
\hline \multirow{2}{*}{ Attribute } & \multicolumn{4}{|c|}{ Physical violence } & \multirow[t]{2}{*}{ Odd ratio } \\
\hline & Yes & $\%$ & No & $\%$ & \\
\hline \multicolumn{6}{|l|}{ Age } \\
\hline$<18$ years & 5 & 7.6 & 61 & 92.4 & $0.37(0.12-1.06)$ \\
\hline$>18$ years & 35 & 19.1 & 149 & 80.9 & $\mathrm{P}<0.05$ \\
\hline No response & 0 & 0.0 & 0 & 0.0 & Insignificant \\
\hline \multicolumn{6}{|l|}{ Edu. (victim) } \\
\hline No formal edu. & 11 & 21.2 & 37 & 71.2 & $1.96(1.7-3.4)$ \\
\hline Elem/sec & 17 & 10.6 & 131 & 81.9 & $\mathrm{P}<0.05$ \\
\hline Pst. sec. & 12 & 30.8 & 24 & 61.5 & Significant \\
\hline \multicolumn{6}{|l|}{ Edu. (assailant) } \\
\hline No formal edu. & 6 & 37.5 & 7 & 43.8 & $6.90(1.3-7.65)$ \\
\hline Elem/sec. & 20 & 16.5 & 96 & 79.3 & $\mathrm{P}<0.05$ \\
\hline Post sec. & 13 & 11.5 & 89 & 78.8 & Significant \\
\hline \multicolumn{6}{|l|}{ Religion } \\
\hline Christian & 16 & 12.9 & 100 & 80.6 & $1.50(0.76-2.99)$ \\
\hline Muslim & 24 & 19.0 & 91 & 72.2 & $\mathrm{P}<0.05$ \\
\hline Other & 0 & 0.0 & 1 & 100 & Insignificant \\
\hline \multicolumn{6}{|l|}{ Circumcised? } \\
\hline Yes & 9 & 40.9 & 12 & 54.5 & $1.14(0.034-3.66)$ \\
\hline No & 31 & 14.2 & 169 & 77.5 & $\mathrm{P}<0.05$ \\
\hline No response & 0 & 0.0 & 11 & 100 & Insignificant \\
\hline \multicolumn{6}{|l|}{ Employed? } \\
\hline Yes & 3 & 4.1 & 66 & 90.4 & \\
\hline No & 33 & 20.9 & 110 & 96.6 & \\
\hline No response & 4 & 20.0 & 16 & 80.0 & \\
\hline \multicolumn{6}{|l|}{ Marital status } \\
\hline Single & 5 & 38.5 & 6 & 46.2 & \\
\hline Married & 29 & 12.7 & 184 & 80.3 & \\
\hline Separated & 6 & 75.0 & 1 & 12.5 & \\
\hline Divorced & 0 & 0.0 & 1 & 100 & \\
\hline Widowed & 0 & 0.0 & 0 & 0.0 & \\
\hline \multicolumn{6}{|l|}{ Type of marriage } \\
\hline Monogamy & 18 & 10.0 & 150 & 83.3 & \\
\hline Polygamy & 12 & 20.3 & 41 & 69.5 & \\
\hline No response & 10 & 83.3 & 1 & 8.3 & \\
\hline
\end{tabular}

Edu = education; elem = elementary; sec = secondary; educated \& unemployed women were more prone to domestic violence much more than illiterate group. 
Table 7. Correlation table between forced sexual intercourse and physical violence in current pregnancy.

\begin{tabular}{cccccc}
\hline \multirow{2}{*}{ Attribute } & \multicolumn{3}{c}{ Forced sex } & \multicolumn{2}{c}{ Chi square } \\
\cline { 2 - 6 } & Yes & $\%$ & No & $\%$ & 81.5336 \\
Physical violence & 23 & 57.5 & 42.5 & 0 & df 4 \\
No physical violence & 15 & 7.8 & 158 & 82.3 & Prob. 0.0000 \\
No response & 0 & 0.0 & 12 & 63.2 & \\
\hline
\end{tabular}

Physical violence directly correlates with sexual violence.

The most unfortunate thing is that most customs and traditional practices support this practice regardless of the well known harmful effect on both maternal and fetal wellbeing. The prevalence of physical violence against pregnant women (15.9\%) found from this research clearly indicates that violence in pregnancy is quite commoner than most of the conditions routinely screened for during antenatal care. The association of such violence with significant maternal and fetal/neonatal morbidity and mortality emphasizes the fact that domestic violence is not just a social problem but a feto-maternal health hazard that requires the input of all stakeholders.

To put an end to this ugly situation is to empower our women through girl child education.

\section{References}

[1] Katherine, J. and Little, M.D. (2000) Screening for Domestic Violence. Postgraduate Medicine, 108, $135-141$.

[2] Koss, N.P., Koss, P.G. and Woodruff, W.Y. (1991) Deleterious Effect of Criminal Victimization on Women’s Health and Medical Utilization. Archives of Internal Medicine, 151, 342-347. http://dx.doi.org/10.1001/archinte.1991.00400020092019

[3] Jewkes, R., Penn, K., Lenin, J. and Ratsaka, M. (2001) Prevalence of Emotional, Physical and Sexual Abuse among Women in Three South African Province. South African Medical Journal, 91, 421-428.

[4] Martin, S.L., Moracco, K.E., Tsui, A.O., et al. (2001) Domestic Violence across Generations; Findings from Norther India. International Journal of Epidemiology, 31, 560-572. http://dx.doi.org/10.1093/ije/31.3.560

[5] Nasir, K., Lonna, H., Gazmararian, J.A., Adam, M.M., et al. (2012) Violence during Pregnancy and the Postpartum Period. VAW Net. www.vanet'org/research/print-document.php?doc_id=3483

[6] Kwawukumen, E.Y. and Kwawukume, S.B. (2001) Violence against Pregnant Women. The Patient Perspective. Nigerian Journal of Clinical Practice, 4, 76-79.

[7] Christina, E.E. (1994) Gender In-Equality of Health in the Third World. Social Science Medicine, 39, 1237-1247. http://dx.doi.org/10.1016/0277-9536(94)90356-5

[8] Aimakhu, C.O., Olayemi, O., Iwe, C.A.B., et al. (2004) Current Causes and Management of Violence against Women in Nigeria. Tropical Journal of Obstetrics and Gynaecology, 21, S7.

[9] Rropachewana, C., Suraiya, K., Hilsham, A. and Hai, A. (2001) Prevalence and Complications of Physical Violence during Pregnancy. European Journal of Obstetrics. Gynecology and Reproductive Biology, 103, 26-29.

[10] Torres, S., Campbell, J., Ryan, J., King, C., Price, P., Stallings, R.Y., et al. (2000) Abuse during and before Pregnancy: Prevalence and Cultural Correlates. Violence and Victims, 15, 303-321.

[11] Krug, E., Linda, D., James, M., et al. (2002) World Report on Violence and Health. WHO. http://www.who.int/violence world report/en/fullWRVH.pdf

[12] Loraine, B., Susan, B. and Gillian, M. (2001) Domestic Violence in Pregnancy. Review. Obstetrics \& Gynecology, 3, 56-59.

[13] The Holy Bible.

[14] Persons, L., Goodwin, M.M. and Peterson, R. (2000) Violence against Women and Reproductive Health: Toward Defining a Role for Reproductive Health Care Services. Maternal and Child Health Journal, 4, 135-140. http://dx.doi.org/10.1023/A:1009578406219

[15] Odujinrin, O. (1993) Wife Battering in Nigeria. International Journal of Gynaecology and Obstetrics, 41, 159-164.

[16] Ezegwui, H.U., Ikeme, A.C. and Onwasigwe, C.N. (2003) Domestic Violence against Pregnant Nigerian Women Ezegui Nigeria Women. Tropical Journal of Obstetrics and Gynaecology, 20, 116-118.

[17] Ameh, N. and Abdul, M.A. (2004) Prevalence of Domestic Violence amongst Pregnant Women in Zaria, Nigeria. An- 
nals of African Medicine, 3, 4-6.

[18] Bauer, H.M. and Rodriguez, M.A. (1995) Letting Compassion Open the Door: Battered Women Disclosure to Medical Providers. Cambridge Quarterly of Healthcare Ethics, 4, 495-465. http://dx.doi.org/10.1017/S0963180100006289

[19] Boseh, X. (2001) Female Genital Mutilation in Developed Countries. The Lancet, 352, 1177-1179. http://dx.doi.org/10.1016/S0140-6736(01)06262-6

[20] Van der Strater, A., King, R., Grinstead, O., Sercifilira, A. and Allen, A. (1995) Couple Communication, Sexual Coercion, and HIV Risk Reduction in Kigali, Rwanda. AIDS, 9, 935-944. http://dx.doi.org/10.1097/00002030-199508000-00016

[21] Jejeebhoy, S.I. (1998) Association between Wife-Beating and Fetal and Infant Death: Impression from a Survey in Rural India. Studies in Family Planning, 29, 300-308. http://dx.doi.org/10.2307/172276

[22] Gremillion, D.H. and Evins, G. (1994) Why Don’t Doctors Identify and Refer Victims of Domestic Violence? North Carolina Medical Journal, 55, 428-432.

[23] Janssen, P.A., Holt, V.L., Sugg, N.K., Emanuel, I., Critchlow, C.M. and Henderson, A.D. (2003) Intimate Partner Violent and Adverse Pregnancy Outcome: A Population-Based Study. American Journal of Obstetrics and Gynecology, 188, 1314-1347. http://dx.doi.org/10.1067/mob.2003.274

[24] Fermandez, F.M. and Krueger, P.M. (1999) Domestic Violence: Effect on Pregnancy Outcome. Journal of American Osteopathic Association, 99, 254-255.

[25] Arbuckle, J., Olson, L., Howard, M., Brillman, J., Anctil, C. and Sklar, D. (1996) Safe at Home? Domestic Violence and Other Homicides among Women in Mexico. Annals of Emergency Medicine, 27, 210-215. http://dx.doi.org/10.1016/S0196-0644(96)70325-6

[26] Michael, C., Jessica, S., Vivian, P. and Halfin, M.D. (2003) Domestic Violence and Sexual Assault. In: De Cherney, A. and Nathan, L., Eds., Current Obstetric and Gynecologic Diagnosis and Treatment, Lange, Vol. 9, 1087-1093.

[27] Koenig, M.A., Lutalo, T., Zhao, F., Nalugoda, F., Wabwire-Mangen, F., Kiwanuka, N., et al. (2003) Domestic Violence in Rural Uganda: Evidence from a Community-Based Study. Bulletin of the World Health Organization, 81, 5360.

[28] Strategic Action Issue Area. African Women’s Right. African Action Home Page. http://www.action-or/action/womenhtm

[29] (1999) Constitution of the Federal Republic of Nigeria. Chapter One Part 2.

[30] Penal Code. Laws of Northern Nigeria.

[31] Halton, A., McFarlane, J. and Anderson, E. (1987) Battering and Pregnancy: A Prevalence Study. American Journal of Public Health, 77, 1337-1339. http://dx.doi.org/10.2105/AJPH.77.10.1337

[32] Burgess, A.W. and Holmstrom, L.L. (1974) Rape Trauma Syndrome. American Journal of Psychiatry, 131, $981-986$.

[33] Bewley, C. (1994) Coping with Domestic Violence during Pregnancy. Nursing Standard, 8, 25-28.

[34] Medical Association Council on Scientific Affairs (1992) Violence against Women: Relevance for Medical Practitioners. JAMA, 267, 3184-3189.

[35] Mazza, D., Dennerstein, L. and Ryan, V. (1996) Physical, Sexual and Emotional Violence against Women: A General Practice-Based Prevalence Study. Medical Journal of Australia, 164, 14-17.

[36] Coker, A.L. and Richter, D.L. (1998) Violence against Women in Sierra Leone; Frequency and Correlates of Intimate Partner and Forced Sexual Intercourse. African Journal of Reproductive Health, 2, 61-72.

[37] Evins, G. and Chescheir, N. (1996) Prevalence of Domestic Violence among Women Seeking Abortion Services. Women's Health Issues, 6, 304-310. http://dx.doi.org/10.1016/1049-3867(95)00012-7 
Scientific Research Publishing (SCIRP) is one of the largest Open Access journal publishers. It is currently publishing more than 200 open access, online, peer-reviewed journals covering a wide range of academic disciplines. SCIRP serves the worldwide academic communities and contributes to the progress and application of science with its publication.

Other selected journals from SCIRP are listed as below. Submit your manuscript to us via either submit@scirp.org or Online Submission Portal.
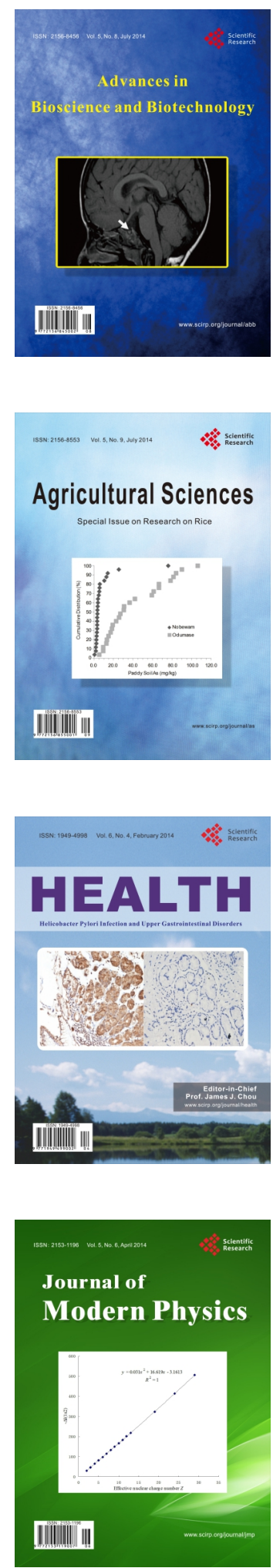
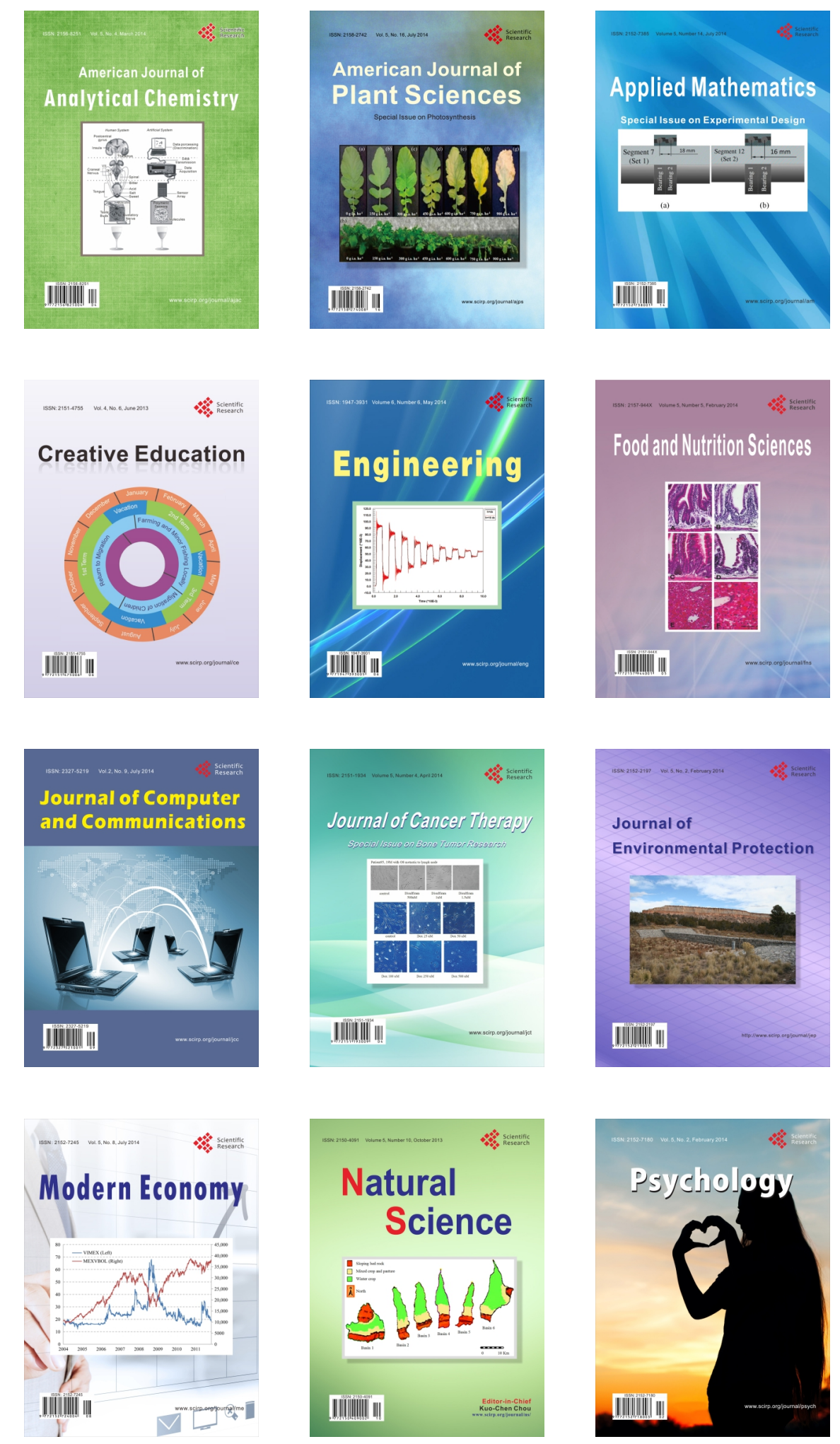